\title{
THE LOCUS IN THE CONTEXT OF LATE ANTIQUE SPAIN
}

\begin{abstract}
At a conference some years ago, I briefly examined the relationship between local power and wine production in Visigothic Spain. On that occasion, I mentioned the transformed legal nature of the locus, a topic I now wish to explore further, in the same geographical scope. The hypothesis is twofold. First, I argue that some recently excavated timber structures are not representative of a change in rural settlement patterns. Second, that despite its terminological ambivalence, the locus evolved from a legal definition to a broader use, and would have been commonly applied to villages in the $6^{\text {th }}$ century. A connection between archaeological evidence and literary sources is suggested..
\end{abstract}

Keywords: Visigothic law, loci, villages, rural settlement, continuity.

\section{OVERVIEW}

$\mathbf{T}$ he last two decades have seen an exceptional increase in the archaeological study of rural settlement during late antiquity in the Spanish provinces. Indeed, many current research premises have become quasi-ideological, and favor a methodological apriorism that takes the fragmentation of social order as a given fact. The caricature of landlords running for their lives while autonomous peasant communities build selfsustaining villages transpires in a number of recent texts on this period. However, it is today clear that Marxist portrayals of a slave economy do not really apply to peasant labor in, say, late Roman Spain, or do so only as gross oversimplifcations of what serfdom correctly entailed ${ }^{1}$. While acknowledging important post-imperial transformations, as well as regional specificities, there is a case to be made for less abrupt reorganizations of the social, hence economic landscape between the late $5^{\text {th }}$ and the very early $7^{\text {th }}$ centuries. One may do so through the lens of production units, and more specifically by the definition of the locus.

Throughout late antiquity, the essential success factor for settlement remained entirely agrarian, based on continuities in techniques and even production channels. According to certain theories that seem currently mainstream, it was agency that changed dramatically, with village communities obtaining important degrees of autonomy. In fact, the impression that the Visigothic monarchy would have found indirect support in such communities does not look illogical on paper. Certainly, urban complexity in the immediate post-imperial setting was much harder to manage, as easily inferred from purportedly comprehensive sources such as Hydatius, for an earlier period, or Isidore of Seville. In addition, an alternative or a partially complementary theory, at least some new rural central places would have been Visigothic,
Adriaan De MAN

United Arab Emirates University adriaandeman@uaeu.ac.ae

DOI: $10.14795 /$ j.v7i4.556

ISSN 2360 - 266X

ISSN-L 2360 - 266X

\footnotetext{
ESMONDE CLEARY 2013, 264-302.
} 
either ethnically or in a sort of freeriding movement of acculturation. No substantive support is available for such a picture, although a migration process did occur, and initial settlement does not seem to have been heavily city-based. The often mentioned sortes Gothicae are necessarily to be seen as fiscal transpositions, which legitimate Theodosian, then Justinian norms. In addition, the correlated figure of the tertia Romanorum configures proof of taxes and rent arrangements, not of actual Germanic colonization, and land ownership often remained in Roman hands ${ }^{2}$. This is however not an entirely closed case, and when revisiting LV 10.1.8 and following laws, the fiscal dimension applies as much to Goths as it does to Romans. An abundance of data is furthermore available regarding initial Germanic indifference towards city dwellers and political intricacies involving the HispanoRoman clans, namely some local families competing against each other to gain legitimacy. This seems the most plausible interpretation, for instance, for the Cantabri of Conimbriga, whose abduction, and three years later the destruction of the entire city, was written down in such dramatic terms by bishop Hydatius of Aquae Flaviae (Chron. 223 and 2413) that one can only interpret this description as a result of some private drama or personal attachment to the until then dominant faction. It fits the overall catastrophist tone of the chronicle well, yet the exceptional nature of the episode, and especially the inexistence of any clear disturbance in the archaeological record during late antiquity, would suggest that daily life was not much affected by the Cantabri leaving the city. What is rather perceptible is a change in urban topography, and an increasing use of perishable and reused building materials. This well documented reality ${ }^{4}$ may be a good starting point for interpreting similar shifts outside the city walls, not only in villae but in other types of construction too.

This physical observation relates directly to explanations about weakening of imperial authority, and transitions to new powers administrating the countryside, potentially even village communities, in addition to, or substituting urban elites (Chavarría Arnau ${ }^{5}$ wrote a clear synopsis on the subject). Not much information is currently available on these non-urban dynamics, and the potentially self-regulating internal management of what one might call hamlets, that is, the modest agglomerations of perishable structures that have been excavated in the Spanish provinces. Vigil-Escalera ${ }^{6}$ was arguably the first to attempt a comprehensive systematization on the configuration and typology of these sunken huts in Spain, based on two then recently excavated sites (La Indiana-Cacera del Valle, in Pinto, and Gózquez de Arriba, San Martín de la Vega, both in the southern Madrid area). The material similarities with a few other sites, in building techniques, organization of space, artifacts, and especially radiocarbon-dated evidence pointing at the 6 th century, led to a suggestion of Slavic and Germanic equivalences. Although chronologically not open for discussion, the ethnic and cultural discussion is outlined in conjectural terms, and the paper remains

\footnotetext{
GOFFART 2010, 65-98.

TRANOY 1974, 171-175.

4 DE MAN 2011, 514-527.

CHAVARRÍA ARNAU 2013, 131-166.

${ }^{6}$ VIGIL-ESCALERA 2000, 223-252.
}

extremely cautious about the non-material (i.e. historical) inferences. Two decades later, archaeological data has become more coherent, with several other units excavated, which led to the image of a profound transformation of the landscape, in which villagers faced a new environment, more prone to animal husbandry, and -- very much underlined -- without supra-local authority ${ }^{7}$. These perspectives are summarized as emanating from a small network of villages along the 6th and 7th centuries, which would then have quickly disintegrated and disarticulated, before re-concentrating as larger, more stable and cohesive villages in the first half of the 9 th century ${ }^{8}$. A large part of such a reasoning stems from academic considerations ${ }^{9}$ on egalitarian forms of settlement, abandoning existing framework and creating new collectivities.

\section{VILLAGES AND LOCI}

I initially based several of my own thoughts on this model ${ }^{10}$, then started to question some angles ${ }^{11}$, and a reactionary disclaimer is now probably in order. One major objection is that the model assumes a full retraction of rural aristocratic pretensions, which would be a unique, and therefore odd situation, from a comparative historical perspective. No doubt change did occur, and drastically so; material and written sources indicate, for instance, a marked reduction of mid-sized villae, or at least their residential use. Whether this traces back to a collapse (Chris Wickham is a central source for this point of view ${ }^{12}$ ) remains to be proven for the entire Hispanic territory, though. No evidence of consistent latifundia-style land arrangements is available to the best of my knowledge ${ }^{13}$, and it is plausible that, in this particular period, a disappearance of villae actually results from better management and territorial concentration of landownership, in which divided parcels end up absorbed in increasingly larger units, through marriage, agreements, or simply the financial ruin of many smaller estates. There is plenty of evidence, both archaeological and written, of extremely wealthy owners with very divided property. The donation and will of Vincent of Huesca are a wonderful $6^{\text {th }}$ century case study, with references to portions of lands and vineyards inside loci, on different estates ${ }^{14}$. It is moreover quite clear (e.g. C.Th. 12.3.2) that in the early to mid- $5^{\text {th }}$ century governments had faced a pervasive problem of curiales trying to sell their farmlands to wealthy aristocrats, presumably in an attempt to avoid paying taxes on their properties. Legislation was repeatedly put into place to counter this, e.g. by barring curiales from seeking patrocinium $^{15}$, hence avoiding taxation on what typically would have been very parceled, disperse, modest property. Even assuming some regional variance, the expression of the excavated very early medieval villages is geographically

\footnotetext{
MARTÍN VISO et alii 2017; VIGIL-ESCALERA 2007, 2009; QUIRÓS CASTILLO 2013.

${ }^{8}$ CARVALHO 2016, 416.

FRANCOVICH/HODGES 2003.

${ }^{10}$ DE MAN 2012a, 151-168.

1 DE MAN 2014, 13-20.

12 WICKHAM 2005

3 DE MAN 2012b, 101-108.

CORCORAN 2003, 215-221.

${ }^{15}$ KEHOE 2007, 165-173.
} 
much more reduced than that of the known surviving villae, and concentrated around Madrid and a few other locations. What sites such as Gózquez, El Pelícano, La Huelga ou La Vega have in common is a sub-rectangular form, a Visigothic chronology, and an occasional use of an irregular stone base. Insisting on the potential exception (that is, peasant self-organization, disappearance of land-based aristocracy, or severe episcopal retraction in the cities) and not on the rule (maintenance of rural potentes and a system of servant dependency) is certainly debatable. The remarkable care of the Toledan kingdom in stipulating fiscal collection procedures through local numerarii chosen by bishops instead of through curiales $^{16}$ tackles the issue of the latter's corruption, not the breakdown of the rural tax collection system. No doubt a new decentralization took place, but not at all unlike that of the later empire, and still tied together through annonary channels. Even in apparently secondary hilltop locations one finds reference to annonarii and erogatores annonae. In addition, forms of stability are also visible when looking at the private boundaries of the lands. Apart from anecdotic evidence on the survival of imperial termini, some toponymical persistence of fundi or villae (e.g. Marciliana, Gomedei, Curmiano, among others ${ }^{17}$ ) remains clear along late antiquity, and there is little factual evidence to support further land division. In fact, LV 10.3 starts with a clear statement: We hereby decree that all ancient landmarks and boundaries shall stand as established in former times, and that they shall not be disturbed or removed. The subsequent laws on property disputes (LV 10.3.2-5) insist in great detail on the recovery of ancient landmarks, and on the boundaries from the time of the Romans.

Though acknowledging social and legal evolutions, and the material reality mentioned above, it might be worthwhile exploring some structural endurances, rather than discontinuities. I wish to do so by framing the locus in this late antique landscape. The working hypothesis is that of a correspondence with rural dwellings such as the ones mentioned above, but in a fundamental incompatibility with independent communities. The main premise is an obvious one, namely the fact that Visigothic legal and descriptive sources do not waste any effort on things foreign to daily life; it is closely followed by a less obvious postulation, that of $6^{\text {th }}$ century social adjustments having produced much lower impacts than some current narratives assume. Isidore of Seville's Etymologies are an interesting source yet need to be read in their proper perspective, as they configure not a direct account of the time in the Spanish regions, but instead, as indicated by the title itself, an attempt at explaining and categorizing words and concepts, many of which of classical, non-Hispanic origin. With regard to the rustic settlement, the text mentions the casa (Etym. 15.12.1), a structure made with timber, sticks and branches; basically, a type of construction with an unsurprisingly widespread tradition, especially in rural areas. Arce referred to these casae when elegantly confronting the idea of a sudden Germanic import $^{18}$. There is certainly no need to look for diffusionist explanations for these agglomerations, even when local

\footnotetext{
${ }_{16}$ CHURCHIN 2018, 225-240

${ }_{17}$ DE MAN 2014, 13-20.

${ }^{18}$ ARCE 2015, 211-217.
}

coarse wares echo some degree of supra-local evolution. In short, the fact that one finds $6^{\text {th }}$ century pottery in a $6^{\text {th }}$ century hut is but logical. An overlapping matter is that ceramic cultures evolve in such a crisscross of influences, preferences, and technological limitations that there is no such thing as a Hispano-Germanic disruption in their production methods, rather original regional evolutions presenting new solutions, especially for the late antique and early medieval contexts ${ }^{19}$. This is of course a generic statement that does not take into account the many local subtleties that transform the matter of pottery studies in an exciting research field. The rule of thumb should however be that of stability in the most modest constituents of rural life, such as manufacturing, agriculture, hut building, and legal stipulations on both property and people.

This material reality fits an administrative background in which small villages are sometimes mentioned, not as critical subjects but indirectly, namely via the qualification of humble figures of authority. Legal sources make profuse reference to individuals identified as seniores loci. These village elites are on occasion portrayed as destitute, and in addition such seniores seem to have been paradoxically young $^{20}$. Radical autarkic perspectives understand them as a yet another confirmation of village autonomy. Yet they seem very articulated with (and in permanent administrative dependency of) central power. I do even wonder if the seniores loci are not in fact the old landowners themselves, instead of sanctioned/elected representatives of a local community. At least on one occasion, Leovigild took captive a senior loci (the eminent person of the region, in Ferry's 1990 translation $^{21}$ ), his family, his riches and his lands, according to John of Biclar (Chron. 575.2). Although admittedly many other seniores could have been peasants, it seems unlikely that there would have been much space for autonomic village communities to thrive, especially under Leovigild's centralizing policies. Local aristocracy survived, on the other hand, not based in villae with mosaic floors but in some other format. Justice was served by them, as iudices loci or territorii, which from the late $6^{\text {th }}$ century onwards became clearly articulated with the bishops in terms of tax collection; the $3^{\text {rd }}$ Synod of Toledo even stipulates that the iudices locorum would have to convene yearly, together with clergy, fiscal and legal officials, to discuss matters of administration ${ }^{22}$. Apart from the pervasive mentions to these judges, the Forum Iudicum is illustrative in terms of paralegal or policing attributions to seniores and priores. Both book 6 and 8 mention how to proceed with indicted and fugitive slaves. In the case of 6.1.1 (Ut domino vel senioribus loci ...), Scott's translation is officials of the district, and in that of 9.1.8 (originally Recared's; 9.1.9 in the manuscript used by $\mathrm{Scott}^{23}$; prioribus loci illius, villicis adque prepositis...), neighbors and authorities of the district. It is perhaps suitable to consider the original text here, and point out that in the extra-urban Spanish territories certain competencies were attributed to indisputably local actors. Furthermore, the translation as district is a debatable option,

\footnotetext{
9 DE MAN/TENTE 2014

20 CARRIÉ 2005, 269-312.

FERRY 1990, 79.

CHURCHIN 2018, 225-240.

23 SCOTT 1910.
} 
and these loci might be better understood as inhabited units, villages that is, especially as these villici and praepositi are also more easily understandable as delegates, officials, or estate managers, and plausibly a combination these. They are elements of the local community, maybe a tenant endorsed by the landowner, and in any case confirmed or else directly appointed by the tax collecting authorities.

Though such an abundance of genitives is revealing, the ambiguity of the term locus needs to be acknowledged, and even its polysemy, as it is used in a wealth of meanings, from unremarkable references to a place or a location, or a room, to the purely legalistic uses of the word, which is to be explored here. It is unreasonable to take all the magistrates loci-orum in an undefined sense, that is, from the place(s), and they instead qualify a small residential area, for which said officials are accountable. This suggests a tangible evolution, as the late Roman locus refers to a clear and different concept. It corresponds to a unit of parceled land, inside a fundus, from which it differs by not containing any buildings, in an equivalence with the area in urban context (Dig. 50.16.211; Flor. 8 Inst.; vide Mommsen ${ }^{24}$ ). Although it is sometimes taken as synonym of the ager ${ }^{25}$, the locus remains unstipulated by its very nature, as it may either form part of a fundus, or comprise more than one, and legal disputes involving loci are always about boundaries, not property ${ }^{26}$. Indeed, a second feature of the locus has to do with the lifespan of its circumscription: it is contextual, adaptive and temporary, as one infers from the source above (Dig. 50.16.60 pr., Ulp. 69), which directly points to land leasing procedures through the creation of $l o c i^{27}$. The integration of Ulpian does not mean that there was a linear transposition between the late empire and the late antique compilation of the Digesta, but as the Visigothic loci are essentially manifestations of a legal context (e.g. LV 15. 3.4. or 9.1.21), this transposition certainly looks as the least farfetched. Florentinus' definition referring an absence of aedificia needs probably to be taken in contrast with the villa, not as an absolute restrictive rule against any sort of secondary rural construction. The $5^{\text {th }}$ century colonate did not dwell in the immediate adjacency of the main residence, and could therefore perhaps be connected to some of the early medieval villages, in other words, to the loci mentioned in the Visigothic sources, hence the terminological and legal evolution. This scenario needs also to be seen in the light of servitudes. Since the classical period, rights of use for farming purposes seem to have been regulated first and foremost through communal cooperation. Ownership, counterintuitively perhaps, mattered less than it did in other forms of property management, such as urban leasing for instance. Indeed, what surfaces through a contrast of imperial laws (e.g. Bannon, on water supply ${ }^{28}$ ) is that an entire community of right-holders would be consulted regarding changes. The entire process was locally organized, and not controlled by a single abusive individual, against which legal action could be taken. What this means is that important forms of rural self-organization had

\footnotetext{
${ }^{24}$ MOMMSEN 1888

${ }^{25}$ BUCK 1983, 8-16.

${ }^{26}$ LONG 1875, 29-31.

27 DE MAN 2017, 107-114.

${ }^{28}$ BANNON 2017, 60-89.
}

been common in the Roman empire, and that villagers and neighbors shared resources that were considered res mancipi (Dig. 8.3.1.1 Ulp. 2 Inst.; Gaius, Inst. 2.17).

This theory on settlement dynamics becomes however problematic when contrasted with perspectives on a supposed fragmentation of local powers, disarticulation of fundi, and reduction of an imperial inspiration on lower level hierarchical structures. In fact, it entails the exact opposite, namely the maintenance of locatio-conductio relationships, meaning that coloni would continue to explore a leased fundus. It represents the most coherent interpretation, given that the colonate remains profoundly rooted in the Visigothic operational logic. The adscripticius, as a rather unfavorable category of colonus, does not even emerge before the 5th century $^{29}$, and becomes fully regulated in the following one (cf. CJ 11.48.24). Classical hiring and letting procedures had been most frequently based on annual payments by the locator, spread over five years, although other forms were usual, namely in provincial context $\mathrm{t}^{30}$. Augustine of Hippo (Ep. 20.29) transmits a story involving the lease of a fundus, the owner receiving a five-year rent paid in advance ${ }^{31}$. But the entire late Roman legislative action on the rural economy insists on ensuring that landowners could meet their fiscal duties, and a powerful set of laws undermined the mobility of the theoretically semi-servile coloni. A more sophisticated census, integrating a differentiated fiscal classification of land ${ }^{32}$, made it virtually impossible to escape tax liabilities. In short, the government forced tenured cultivators to remain in their village, and at a later stage, in their estates, which became their legal origo, a novelty that however had probably been a non-mandatory reality anyway. The formal difference was that an early imperial tenant might decide not to renew a contract and move elsewhere -- again, to which extent this actually happened is a different question. In the western provinces, this is a complex and gradual process that became fully enforceable only in the very late fourth century (indeed in its last months; e.g. C.Th. 11.1.26, from 399). The same principle persists in Visigothic law, as seen along the Forum Iudicum's entire Book 10. From this perspective, the scenario looks less fertile for arguments about the decomposition of an economical system. On the contrary, it points to strong continuities in a socioeconomically stable relationship between coloni and landowners. Such relationships materialize as profoundly advantageous to all, at the formal, consuetudinary and even symbolic levels, which are precisely the ones seniores and iudices loci find their legitimacy in. The substantiation of late antique villages would therefore be based on conservativeness and loyalty -- not, as often ideologically suggested, on peasant liberation or power vacuums. This should not come as any surprise, and it plugs directly into the historical, and increasingly archaeological reality of widespread settlement with irregular plans and timber buildings, and immense regional variance in the West, since imperial times ${ }^{33}$. Timber had obviously been used during the entire Hispano-Roman

\footnotetext{
${ }^{29}$ DOMÍNGUEZ AGUDO 2003, 113

${ }^{30}$ DU PLESSIS 2012.

${ }^{31}$ KEHOE 2007.

32 DE MAN 2020, 311-324.

33 ESMONDE CLEARY 2013, 264-302.
} 
period $^{34}$, and perishable construction materials seem to have become predominant during late antiquity. This chronology may not be archaeologically documented at a convenient scale, due to a fragile and unsophisticated nature, as well as the lack of associated imported materials. But the technique of post-imperial wooden construction is ubiquitous, and widely observable in 5 th century levels at the villae I am aware of, for instance simply through postholes.

\section{CONCLUSIONS}

Until at least the very late $6^{\text {th }}$ century, production and maintenance of local agency need to be understood in a balance between the the villulae and reinvented villae, the curial, episcopal and monastic powers, and still a handful of new central administrative places, both in Suevic and Visigothic context. Could these all be loci, again formally defined, instead of in a literary, generic use of the term? As stated above, not in a classical sense, but one wonders if a strict legal equivalence with villages works for late antiquity. Martin $^{35}$ pointed out that the $12^{\text {th }}$ Synod of Toledo (681) used the word locus for villulae, territoria, and vici, and that it therefore simply applies to a rural habitat dependent of a central place. She provides a wide variety of examples from John of Biclar, several Toledan synods, and the Liber Iudicum, and a compelling argument for the occasionally clear fiscal nature of the locus, even as a sort of equivalent of the fundus. This requires a proper chronological evaluation; one needs to bear in mind that an imperial villa may very well be ruined and reoccupied, without correspondingly changes in land exploitation $^{36}$. Generalizations on territorial settlement modifications have become impractical, though, as some late antique rural sites have medieval continuities while others do not. Despite these complicated localisms, some overlapping realities do become visible at regional level, for instance northwestern Lusitania, where a general reduction of both human activity and of forestation occurred from the $7^{\text {th }}$ century onwards (a picture that much later would become heavily transformed again, in the context of medieval urban councils and their use of common areas; see Martín Viso ${ }^{37}$ for details). For the $6^{\text {th }}$ century, though, it is probably unwise to deliberately ignore institutionalist and solid conservative frameworks, and start constructing bottom-up models on limited, and otherwise explainable, material culture.

\section{REFERENCES}

ARCE 2015

Arce, J., Isidoro y el Paisaje Rural Contemporáneo (s. VII), Antiquité Tardive 23, 211-217.

\section{BANNON 2017}

Bannon, C., Fresh Water in Roman Law: Rights and Policy, Journal of Roman Studies 107, 60-89.

\section{BROGIOLO/CHAVARRÍA ARNAU 2008}

Brogiolo, G.P./ Chavarría Arnau, A. (2008), El final de las villas y las transformaciones del territorio rural en Occidente (siglos V-VIII). In: Fernández Ochoa, C./ García Entero, V./Gil Sendino, F. (ed.), Las villae tardorromanas

\footnotetext{
${ }^{34}$ MORILLO CERDÁN/HERMANNS,/SALIDO DOMÍNGUEZ 2019.

${ }^{35}$ MARTIN 2003, 17.

${ }^{36}$ BROGIOLO/CHAVARRÍA ARNAU 2008, 193-213.

${ }^{37}$ MARTÍN VISO 2020, 226-245.
}

en el Occidente del Império: arquitectura y función, IV Coloquio Internacional de Arqueología en Gijón (Gijón), 193-213

\section{BUCK 1983}

Buck, R. J., Agriculture and Agricultural Practice in Roman Law (Wiesbaden: Franz Steiner Verlag).

\section{CARRIÉ 2005}

Carrié, J.-M., Developments in provincial and local administration. In: Bowman, A. (ed.), The Cambridge Ancient History XII, The crisis of Empire, AD 193-337 (Cambridge), 269-312.

\section{CARVALHO 2016}

Carvalho, P., O final do mundo romano:(des)continuidade e/ou (in)visibilidade do registonas paisagens rurais do interior norte da Lusitania. In: d'Encarnação, J./Lopes, M./ Carvalho, P. (ed.), A Lusitânia entre Romanos e Bárbaros (Coimbra-Mangualde), 397-435.

\section{CHAVARRÍA ARNAU 2013}

Chavarría Arnau, A., ¿Castillos en el aire? Paradigmas interpretativos "de moda" en la arqueología medieval Española. In: De Mahoma a Carlomagno, Los Primeros Tiempos (Siglos VII-IX) (Estella), 131-166

\section{CHURCHIN 2018}

Churchin, L., Curials and local government in Visigothic Hispania, Antiquité Tardive 26, 225-240.

\section{CORCORAN 2003}

Corcoran, S., The Donation and Will of Vincent of Huesca: Latin Text and English Translation, Antiquité Tardive 11, 215-221.

\section{DE MAN 2011}

De Man, A., Recent archaeological research on late and postRoman Conimbriga, Madrider Mitteilungen 52, 514-527.

\section{DE MAN 2012a}

De Man, A., Security and settlement issues in late antique western Spain, Oriental Studies - Journal of Oriental and Ancient History 1, 151-168.

DE MAN 2012b

De Man, A., Forms of late antique settlement in Lusitania, The very beginning of Europe? Cultural and Social Dimensions of Early-Medieval Migration, Relicta 7, 101108.

\section{DE MAN 2014}

De Man, A., Definindo a Lusitânia tardo-antiga: alguns aspectos regionais de defesa e controlo (s. V-VI). In: Catalán Ramos, R./Fuentes Melgar, P./Sastre Blanco J. (ed.), Las Fortificaciones en la tardoantiguedad: Élites y articulación del territorio entre los siglos V-VIII d.C. (Madrid), 13-20.

\section{DE MAN 2017}

De Man, A., Vinho, espaço e poderes na Antiguidade tardia. In: Sousa, L./Paixão, M. (ed.), Nunc est bibendum, Vinho, Identidades e Arte de Viver (Lisboa-Palmela), 107-114.

\section{DE MAN 2020}

De Man, A., Diocleciano e Constantino. In: Brandão, J./ Oliveira, F. (ed.), História de Roma Antiga, volume II: Império Romano do ocidente e romanidade hispânica (Coimbra), 311-324.

\section{DE MAN/TENTE 2014}

De Man, A./Tente, C. (eds.), Estudos de Cerâmica Medieval, O Norte e o Centro de Portugal, séculos IX a XII (Lisboa: Instituto de Estudos Medievais).

\section{DU PLESSIS 2012}

Du Plessis, P., Letting and Hiring in Roman Legal Thought: 27 BCE - 284 CE (Leiden: Brill). 


\section{ESMONDE CLEARY 2013}

Esmonde Cleary, S., The Roman West, AD 200-500. An Archaeological Study (Cambridge: University Press).

FERRY 1990

Ferry, J., John of Biclar and his Chronicle (Houston: Rice University).

FRANCOVICH/HODGES 2003

Francovich, R./Hodges, R., Villa to Village, The Transformation of the Roman Countryside in Italy, c. 400- 1000 (London: Duckworth).

GOFFART 2010

Goffart, W., The Technique of Barbarian Settlement in the Fifth Century: A Personal, Streamlined Account with Ten Additional Comments, Journal of Late Antiquity 3(1), 65-98.

\section{KEHOE 2007}

Kehoe, D., Law and the Rural Economy in the Roman Empire (Ann Arbor: University of Michigan Press).

LONG 1875

Long, G., Ager. In: A Dictionary of Greek and Roman Antiquities (London), 29-31.

MARTIN 2003

Martin, C., La Géographie du Pouvoir dans l'Espace Visigothique (Villeneuve d'Ascq: Presses Universitaires du Septentrion).

MARTÍN VISO et alii 2017

Martín Viso, I./Rubio Díez, R./López Sáez, J. A./Ruiz Alonso, M./Pérez Díaz, S., La formación de un nuevo paisaje en el centro de la península ibérica en el periodo posromano: el yacimiento de La Genestosa (Casillas de Flores, Salamanca), AEspA 90, 7-28.

MARTÍN VISO 2020

Martín Viso, I., Territorios resilientes: mancomunales y concejos en el sur del Duero durante la Edad Media, Vínculos de Historia 9, 226-245.
MORILLO CERDÁN/HERMANNS/SALIDO DOMÍNGUEZ 2019

Morillo Cerdán, Á., Hermanns, M. H., Salido Domínguez, J. (ed.), Ephemeral Archaeology. Products and perishable materials in the archaeological record of Roman times (Nünnerich-Asmus Verlag \& Media, Mainz am Rhein).

QUIRÓS CASTILLO 2013

Quirós Castillo, J. A. (ed.). El poblamiento rural de época visigoda en Hispania. Arqueología del campesinado en el interior peninsular (Bilbao: Universidad del País Vasco).

\section{SCOTT 1910}

Scott, S. P., The Visigothic Code (Forum Judicum) (Boston: Boston Book Company)

\section{TRANOY 1974}

Tranoy, A., Hydace. Chronique. Tome I: Introduction, texte critique (Paris, Editions du Cerf).

VIGIL-ESCALERA GUIRADO 2000

Vigil-Escalera Guirado, A., Cabañas de época visigoda: evidencias arqueológicas del Sur de Madrid. Tipología, elementos de datación y discusión, AEspA 73, 223-252.

VIGIL-ESCALERA GUIRADO 2007

Vigil-Escalera Guirado, A., Granjas y aldeas altomedievales al norte de Toledo, AEspA 80, 239-284.

VIGIL-ESCALERA GUIRADO 2009

Vigil-Escalera Guirado, A., Las aldeas altomedievales madrileñas y su proceso formativo. In: Quirós Castillo, J. (ed.), The Archaeology of Early Medieval Villages in Europe (Bilbo), 315-339.

WICKHAM 2005

Wickham, C., Framing the Early Middle Ages, Europe and the Mediterranean 400-800 (Oxford: University Press). 